\title{
Cytokines Suppress Human Islet Function Irrespective of Their Effects on Nitric Oxide Generation
}

\author{
Décio L. Eizirik, " Stellan Sandler, ${ }^{\star}$ Nils Welsh, " Marina Cetkovic-Cvrlje, " Audrey Nieman, " David A. Geller, \\ Daniel G. Pipeleers," Klaus Bendtzen," and Claes Hellerström* \\ ${ }^{*}$ Department of Medical Cell Biology, Uppsala University, S-751 23 Uppsala, Sweden; ${ }^{\ddagger}$ Department of Surgery, University of Pittsburgh, \\ Pittsburgh, Pennsylvania 15261; ${ }^{8}$ Department of Metabolism and Endocrinology, Vrije Universiteit Brussels and $\beta$-Cell Transplant, \\ 1090 Brussels, Belgium; and "Laboratory of Medical Immunology, Medical Department TTA, University Hospital, DK-2200N \\ Copenhagen, Denmark
}

\begin{abstract}
Cytokines have been proposed as inducers of $\boldsymbol{\beta}$-cell damage in human insulin-dependent diabetes mellitus via the generation of nitric oxide (NO). This concept is mostly based on data obtained in rodent pancreatic islets using heterologous cytokine preparations. The present study examined whether exposure of human pancreatic islets to different cytokines induces NO and impairs $\beta$-cell function. Islets from 30 human pancreata were exposed for 6-144 $\mathrm{h}$ to the following human recombinant cytokines, alone or in combination: IFN- $\gamma(1,000 \mathrm{U} / \mathrm{ml})$, TNF- $\alpha$ $(1,000 \mathrm{U} / \mathrm{ml})$, IL-6 $(25 \mathrm{U} / \mathrm{ml})$, and IL-1 $\beta(50 \mathrm{U} / \mathrm{ml})$. After $48 \mathrm{~h}$, none of the cytokines alone increased islet nitrite production, but IFN- $\gamma$ induced a $20 \%$ decrease in glucose-induced insulin release. Combinations of cytokines, notably IL-1 $\beta$ plus IFN- $\gamma$ plus TNF- $\alpha$, induced increased expression of inducible NO synthase mRNA after $6 \mathrm{~h}$ and resulted in a fivefold increase in medium nitrite accumulation after $48 \mathrm{~h}$. These cytokines did not impair glucose metabolism or insulin release in response to $16.7 \mathrm{mM}$ glucose, but there was an $80 \%$ decrease in islet insulin content. An exposure of $144 \mathrm{~h}$ to IL-1 $\beta$ plus IFN- $\gamma$ plus TNF- $\alpha$ increased NO production and decreased both glucose-induced insulin release and insulin content. Inhibitors of NO generation, aminoguanidine or $\boldsymbol{N}^{\mathbf{G}}$-nitro-L-arginine, blocked this cytokine-induced NO generation, but did not prevent the suppressive effect of IL-1 $\beta$ plus IFN- $\gamma$ plus TNF- $\alpha$ on insulin release and content. In conclusion, isolated human islets are more resistant to the suppressive effects of cytokines and NO than isolated rodent islets. Moreover, the present study suggests that NO is not the major mediator of cytokine effects on human islets. (J. Clin. Invest. 1994. 93:1968-1974.) Key words: $\beta$-cells $\bullet$ nitric oxide $\bullet$ interleukin- $\beta \bullet$ tumor necrosis factor- $\alpha \bullet$ interferon- $\gamma$
\end{abstract}

\section{Introduction}

The clinical manifestation of insulin-dependent diabetes mellitus (IDDM $)^{1}$ is preceded by a long prodromal period ( 1 ). Dur-

Address correspondence to Décio L. Eizirik, Department of Medical Cell Biology, Uppsala University, Biomedicum, P.O. Box 571, S-751 23 Uppsala, Sweden.

Received for publication 5 November 1993 and in revised form 29 December 1993.

1. Abbreviations used in this paper: AG, aminoguanidine; GAPDH, glyceraldehyde 3-phosphate dehydrogenase; IDDM, insulin-depen-

J. Clin. Invest.

(C) The American Society for Clinical Investigation, Inc. $0021-9738 / 94 / 05 / 1968 / 07 \$ 2.00$

Volume 93, May 1994, 1968-1974 ing this period a negative balance between $\beta$-cell damage $(1,2)$ and $\beta$-cell repair ( 3 ) will decrease the number and function of $\beta$-cells, eventually culminating in overt hyperglycemia. Identification of mediators of $\beta$-cell destruction and of mechanisms involved in $\beta$-cell repair may help develop strategies favoring $\beta$-cell survival in the early stages of the disease $(2,3)$.

Cytokines, particularly IL-1, have been proposed as potential mediators of $\beta$-cell damage in $\operatorname{IDDM}(4,5)$. In vitro exposure of rodent islets to human IL-1, alone or in combination with TNF- $\alpha$ and/or IFN- $\gamma$, induces suppression and loss of $\beta$-cells, as judged by electron microscopy and DNA measurements (4-6). It is noteworthy that IL- $1 \beta$ is cytodestructive to $\alpha$ - and $\beta$-cells in whole rat islet preparations but lacks this effect in purified $\alpha$ - and $\beta$-cell preparations, where it exerts only a $\beta$-cell-selective suppression of cell function (7). These deleterious effects of IL-1 in rat islets are related to generation of the radical nitric oxide (NO) (8-10). NO forms iron-nitrosyl complexes with enzymes containing FeS, like the Krebs cycle enzyme aconitase, leading to inhibition of aconitase activity (9), decrease in glucose and amino acid metabolism $(6,9)$, and decrease in ATP generation (6). In mouse islets, IL-1 also impairs insulin release in parallel to NO generation (11-13), but this is not associated with an impairment in mitochondrial function or ATP generation (11-13).

Conflicting results have been reported from studies with human islets (14-18), possibly as a result of a wide variability in the studied preparations. The present work took advantage of the availability of standardized human islet preparations of well known cell composition and function $(17,19)$. Using these well defined preparations, we demonstrated recently that IL- $1 \beta$ alone does not inhibit function or induce NO generation by human islets (17). In the present study, islets obtained from 30 different cadaveric organ donors were used to characterize the effects of cytokines known to affect rodent islet function (4-6), namely IL- $1 \beta$, TNF- $\alpha$, IFN- $\gamma$, and IL-6, alone or in combinations, on the function and NO generation by human islets.

\section{Methods}

Cytokines and chemicals. Human recombinant IL-1 $\beta$ was kindly donated by Dr. S. Gillis (Immunex Corp., Seattle, WA) and had a bioactivity of $50 \mathrm{U} / \mathrm{ng}$. Human recombinant TNF- $\alpha$ and IFN- $\gamma$ were provided by Dr. G. R. Adolf (Ernst-Boehringer Institute, Vienna, Austria) and had a bioactivity of 50 and $10 \mathrm{U} / \mathrm{ng}$, respectively. Human recombinant IL-6 was a kind gift from Dr. T. Hirano (Dainippon, Osaka, Japan ) and had a bioactivity of $5 \mathrm{U} / \mathrm{ng}$. The cytokines were tested for

dent diabetes mellitus; iNOS, inducible form of nitric oxide synthase; KRBH, KRB supplemented with Hepes and BSA; L-nitroarg, $N^{\mathrm{G}}$-nitro-L-arginine; NO, nitric oxide. 
bioactivity using EL4 cells (IL-1 $\beta$ ) (20), B9 hybridoma cells (IL-6) (21), L-M mouse connective tissue cells (TNF- $\alpha$ ) (22), and potentiation of TNF- $\alpha$ production by human blood monocytes (IFN- $\gamma$ ) (23). Bioactivities of the cytokines were compared with corresponding international reference preparations (National Institute for Biological Standards and Controls, London, UK). The endotoxin contents of the cytokine preparations did not exceed $1 \mathrm{pg} / \mu \mathrm{g}$ cytokine, as tested in a chromogenic Limulus amebocyte lysate assay (Struers, Rødovre, Denmark).

The chemicals were obtained from the following sources: BSA (fraction V) from Miles Laboratories (Slough, UK); culture medium RPMI 1640, FCS, and L-glutamine from Northumbria Biologicals (Cramlington, UK); naphthylenediamine dihydrochloride, sulfanilamide, aminoguanidine (AG), $N^{\mathrm{G}}$-nitro-L-arginine (L-nitroarg), and Hepes from Sigma Chemical Co. (St. Louis, MO); $\left[\alpha-{ }^{32} \mathrm{P}\right] \mathrm{dCTP}$, D[U- ${ }^{14} \mathrm{C}$ ] glucose, and Megaprime DNA labeling system from Amersham International (Aylesbury, UK); agarose from FMC Corp. BioProducts (Rockland, ME); and MagnaGraph nylon transfer membrane from Micron Separation Inc. (Westboro, MA). All other chemicals of analytical grade were obtained from E. Merck (Darmstadt, Germany) or from Sigma Chemical Co.

Islet isolation. Over a period of $18 \mathrm{mo}, 30$ pancreata were excised from adult cadaveric organ donors, transported to the Central Unit of the $\beta$-Cell Transplant, Brussels, and the islets were isolated as described recently (19). The mean age of the donors $( \pm$ SEM) was $32 \pm 3$ yr (range of 9-61 yr). Aliquots of the islet-enriched fraction were examined routinely by electron microscopy $(n=30)$, which indicated $8.2 \pm 1.0 \%$ dead cells and $2.4 \pm 1.1 \%$ exocrine cells in the preparations. The prevalence of insulin- and glucagon-positive cells, as evaluated by light microscopical examination of immunocytochemically stained islets, was $51 \pm 3$ and $8 \pm 1 \%$, respectively. The islet insulin content was $1.34 \pm 0.11$ ng insulin/ng DNA.

Islet culture. After isolation in Brussels, the islets were cultured in medium HAM F10 containing $6.1 \mathrm{mM}$ glucose supplemented with $0.5 \%$ BSA, $0.08 \mathrm{mg} / \mathrm{ml}$ penicillin, and $0.1 \mathrm{mg} / \mathrm{ml} \mathrm{streptomycin.} \mathrm{The}$ culture period varied between 1 and $8 \mathrm{~d}$ (mean \pm SEM, $4.5 \pm 0.4 \mathrm{~d})$, and the islets were subsequently sent by air from Brussels to Uppsala. A detailed description of this procedure and of functional tests on human islets under different culture conditions has been presented previously (19). The human islets were then cultured free-floating in groups of $100-150$ islets per dish in medium RPMI 1640 containing $5.6 \mathrm{mM}$ glucose and supplemented with $10 \%$ FCS, benzylpenicillin (100 U/ $\mathrm{ml})$, and streptomycin $(0.1 \mathrm{mg} / \mathrm{ml})$, and the medium was changed every $2 \mathrm{~d}$. These culture conditions have been shown to preserve the functional activity of human islets for over $2-3 \mathrm{wk}$ in culture $(17,19$, and Eizirik, D. L., unpublished data). After 5-6 d in culture, the medium was supplemented with different cytokines (IL-6, $25 \mathrm{U} / \mathrm{ml}$; IFN$\gamma, 1,000 \mathrm{U} / \mathrm{ml} ; \mathrm{TNF}-\alpha, 1,000 \mathrm{U} / \mathrm{ml}$; and IL- $1 \beta, 50 \mathrm{U} / \mathrm{ml}$ ), alone or in combinations, and the culture continued for $6 \mathrm{~h}, 30 \mathrm{~h}, 48 \mathrm{~h}$, or $6 \mathrm{~d}$. The cytokine concentrations used in the present experiments were adopted from data obtained in rat and mouse pancreatic islets $(6,9,11,24$, and Cetkovic-Cvrlje, M., and D. L. Eizirik, manuscript submitted for publication). Note that the $25 \mathrm{IU} / \mathrm{ml}$ IL-6 (new National Institute for Biological Standards and Controls Standard) used in the present experiments is biologically equivalent to $2,500 \mathrm{U} / \mathrm{ml}$ IL-6 used in our previous study on effects of IL-6 on rat pancreatic islets (24). A detailed study of the effects of IL- $1 \beta$ alone on human pancreatic islets was reported recently (17), and we therefore did not repeat these experiments in the present study. In the current series of experiments, we evaluated both the effects of $48 \mathrm{~h}$ and $6 \mathrm{~d}$ of exposure to cytokines on human islet function and survival. In the latter case, the combination of cytokines used was IL- $1 \beta$ plus TNF- $\alpha$ plus IFN- $\gamma$. In the final three to five experiments of this series, the islets were also exposed to inhibitors of NO production, i.e., AG or L-nitroarg $(8,9,25)$. When islets were exposed to the cytokines for $6 \mathrm{~d}$, fresh cytokines and/or AG or L-nitroarg were added every $2 \mathrm{~d}$, after change of medium.

Islet insulin release. DNA and insulin contents and glucose oxidation. After exposure to the different cytokines, samples from the me- dium were taken for assessment of insulin (26) or nitrite concentrations ( see below). The islets were then recovered and used for determination of acute glucose-stimulated insulin release and insulin and DNA contents, as described previously (19). Briefly, triplicate groups of 7-10 islets each were incubated in sealed glass vials containing 0.25 $\mathrm{ml} \mathrm{KRB} \mathrm{(27)} \mathrm{supplemented} \mathrm{with} 10 \mathrm{mM}$ Hepes and $2 \mathrm{mg} / \mathrm{ml}$ BSA $(\mathrm{KRBH})$. During the first hour of incubation at $37^{\circ} \mathrm{C}\left(\mathrm{O}_{2}: \mathrm{CO}_{2} ; 95: 5\right)$, the $\mathrm{KRBH}$ contained $1.7 \mathrm{mM}$ glucose. The buffer was then removed carefully and replaced by KRBH containing $16.7 \mathrm{mM}$ glucose, and the islets were incubated for a further $60 \mathrm{~min}$.

For measurements of islet glucose oxidation rates, triplicate groups of $10-15$ islets were transferred to glass vials containing $D-\left[U-{ }^{14} \mathrm{C}\right]-$ glucose and nonradioactive glucose to a final concentration of 1.7 or $16.7 \mathrm{mM}$ glucose, and islet glucose oxidation was measured as described previously (28).

Nitrite determination. Aliquots of the culture medium $(80 \mu \mathrm{l})$ were deproteinized by the addition of $20 \mu \mathrm{l} 35 \%$ sulfosalicylic acid. Samples were incubated for $15 \mathrm{~min}$ at $0^{\circ} \mathrm{C}$ and then centrifuged for $15 \mathrm{~min}$ at $12,000 \mathrm{~g} .10 \mu \mathrm{l}$ of $0.5 \%$ naphthylenediamine dihydrochloride was added to the supernatant, together with $5 \%$ sulfonilamide and $25 \%$ concentrated $\mathrm{H}_{3} \mathrm{PO}_{4}(9)$. The reaction was carried out at $60^{\circ} \mathrm{C}$ for 1 min, and the absorbance was measured at $546 \mathrm{~nm}$ in a spectrophotometer (DU-62; Beckman Instruments, Inc., Palo Alto, CA ) against a standard curve.

Northern blot analysis. Total RNA was extracted by the guanidine isothiocyanate method (29). After extraction, the RNA samples (10$15 \mu \mathrm{g}$ ) were electrophoresed on a $1 \%$ agarose gel containing $2.2 \mathrm{M}$ formaldehyde. After acridine orange staining of the gel to document similar sample loading, the RNA was transferred onto a nylon membrane. In the first series of experiments, Northern blots prepared with RNA obtained from islets exposed for $6 \mathrm{~h}$ to cytokines were hybridized sequentially to ${ }^{32} \mathrm{P}$-labeled cDNA probes coding either for the inducible form of nitric oxide synthase (iNOS) from human hepatocytes (30) or, as internal control, for human glyceraldehyde 3-phosphate dehydrogenase (GAPDH) (American Type Culture Collection, Rockville, MD). GAPDH mRNA content is unaffected by islet exposure to IL-1 $\beta(31)$. In a second series of experiments, islets were exposed for $30 \mathrm{~h}$ to cytokines, and the Northern blots were sequentially hybridized to cDNA probes coding for the rat insulin I gene (pRI-7; 32) and GAPDH. Hybridization and autoradiography were performed as described previously (31). Densitometric analysis of the autoradiograms was performed after nonsaturating exposure with a densitometer (Quick Scan Jr.; Helena Laboratories, Beaumont, TX). In all experiments the values obtained by densitometric scanning of the blots hybridized with the probe for rat insulin I were corrected by the values obtained with hybridization with the GAPDH probe.

Statistical analysis. Data are presented as means \pm SEM, and groups of data were compared using Student's paired or unpaired $t$ tests, as appropriate. When multiple comparisons were performed, the data were analyzed by ANOVA followed by group comparisons using the Student's $t$ test. The $P$ values were corrected for multiple comparisons using the Bonferroni method (33). In all experimental series, each islet preparation (i.e., islets obtained from one donor) was considered as one individual observation. When experiments were performed in triplicate, a mean was calculated and considered as one separate observation.

\section{Results}

Islet recovery (i.e., percentage of islets remaining in culture) after $48 \mathrm{~h}$ of exposure to the different combinations of cytokines was $97-100 \%$ in all experimental groups. The presence of cytokines did not modify the islet DNA content but significantly decreased islet insulin content in the following combinations: IFN- $\gamma$ plus TNF- $\alpha$ plus IL-6, IL- $1 \beta$ plus TNF- $\alpha$ plus IFN- $\gamma$, or IL- $1 \beta$ plus TNF- $\alpha$ plus IFN- $\gamma$ plus IL-6 (Table I). None of the cytokines alone decreased islet insulin content. IFN- $\gamma$, TNF- $\alpha$, IL-6 (Table I), or IL- $\beta$ alone (17) failed to 
Table I. Effects of a 48-h Exposure to Cytokines on Insulin and DNA Content or Nitrite Production of Human Pancreatic Islets

\begin{tabular}{lccc}
\hline \multicolumn{1}{c}{ Cytokines } & Insulin content & DNA content & Medium nitrite \\
\hline & $n g / 10$ islets & $n g / 10$ islets & pmol/islet $\times 48 h$ \\
None & $433 \pm 132$ & $420 \pm 46$ & $7.1 \pm 2.5$ \\
IFN- $\gamma$ & $486 \pm 121$ & $415 \pm 53$ & $9.5 \pm 1.2$ \\
IL-6 & $311 \pm 71$ & $362 \pm 59$ & $12.6 \pm 0.6$ \\
TNF- $\alpha$ & $274 \pm 52$ & $416 \pm 56$ & $16.5 \pm 2.2$ \\
IFN- $\gamma$ plus TNF- $\alpha$ & $245 \pm 51$ & $421 \pm 54$ & $23.7 \pm 8.8$ \\
IFN- $\gamma$ plus IL-6 & $252 \pm 60$ & $423 \pm 57$ & $18.4 \pm 5.1$ \\
TNF- $\alpha$ plus IL-6 & $237 \pm 35$ & $464 \pm 68$ & $21.9 \pm 7.8$ \\
IFN- $\gamma$ plus TNF- $\alpha$ & & & \\
$\quad$ plus IL-6 & $156 \pm 30^{*}$ & $473 \pm 65$ & $12.2 \pm 3.9$ \\
IL-1 $\beta$ plus TNF- $\alpha$ & & & \\
$\quad \begin{array}{l}\text { plus IFN- } \gamma \\
\text { IL- } 1 \beta \text { plus TNF- } \alpha\end{array}$ & $91 \pm 19^{\ddagger}$ & $456 \pm 65$ & $37.4 \pm 5.1^{\ddagger}$ \\
$\quad$ plus IFN- $\gamma$ plus IL-6 & $84 \pm 14^{\ddagger}$ & $479 \pm 98$ & $24.4 \pm 1.9^{*}$ \\
\hline
\end{tabular}

Groups of islets were isolated and exposed to IFN- $\gamma 1,000 \mathrm{U} / \mathrm{ml}$, IL- 6 $25 \mathrm{U} / \mathrm{ml}$, TNF- $\alpha 1,000 \mathrm{U} / \mathrm{ml}$, and IL- $1 \beta 50 \mathrm{U} / \mathrm{ml}$, as described in Methods. Values are means \pm SEM of 8-10 experiments (insulin content and DNA content) or 3-4 experiments (nitrite determination). ${ }^{*} P<0.05,{ }^{\ddagger} P<0.01$, respectively, for a chance difference vs noncytokine-treated control islets.

induce NO production, as judged by medium nitrite accumulation. However, combinations of cytokines, i.e., IL- $1 \beta$ plus TNF- $\alpha$ plus IFN- $\gamma$ or IL- $1 \beta$ plus TNF- $\alpha$ plus IFN- $\gamma$ plus IL- 6 , induced a three- to fivefold increase in medium nitrite content. Moreover, $6 \mathrm{~h}$ of exposure to a combination of IL- $1 \beta$ plus TNF- $\alpha$ plus IFN- $\gamma$ induced a clear expression of iNOS mRNA (Fig. 1). The transcript was $\approx 4.5 \mathrm{~kb}$ in length, similar to that induced in hepatocytes by a combination of cytokines (30). Expression of iNOS mRNA was studied after $6 \mathrm{~h}$ of exposure to cytokines based on previous observations in human hepatocytes and hamster insulin-producing cells, showing that iNOS mRNA expression peaked after 6-8 $\mathrm{h}$ of exposure to cytokines $(30,34)$ and returned to basal levels after 24-48 $\mathrm{h}(30)$. In deed, in two experiments where expression of iNOS mRNA in human islets was evaluated after $30 \mathrm{~h}$ of exposure to cytokines, there was a less marked expression of iNOS mRNA than that observed after $6 \mathrm{~h}$ (data not shown). Expression of GAPDH mRNA, used as an internal control, was not modified (Figs. 1 and 2).

It has been shown previously that IL-1-induced NO production by rat pancreatic islets induces an early severe impairment in $\beta$-cell glucose oxidation $(6,35)$. To test if this was also the case for human pancreatic islets, rates of glucose oxidation in the presence of $16.7 \mathrm{mM}$ glucose were evaluated after $48 \mathrm{~h}$ of exposure to different combinations of cytokines. Control islets oxidized $188 \pm 21$ pmol glucose $/ 10$ islets $\times 90$ min (mean \pm SEM; $n=3$ ), while islets exposed to IL- $1 \beta$ plus TNF- $\alpha$ plus IFN- $\gamma$ or IL- $1 \beta$ plus TNF- $\alpha$ plus IFN- $\gamma$ plus IL- 6 oxidized $226 \pm 43$ and $217 \pm 17 \mathrm{pmol} / 10$ islets $\times 90 \mathrm{~min}$, respectively $(n=3)$. Thus, induction of NO by combinations of cytokines was not accompanied by a decrease in the glucose oxidation rates. The same combinations of cytokines and the combination IFN- $\gamma$ plus IL-6 induced a marked increase in medium insulin accumulation (Table II), without affecting insulin release in response to $16.7 \mathrm{mM}$ glucose. However, at this stage the cytokines tended

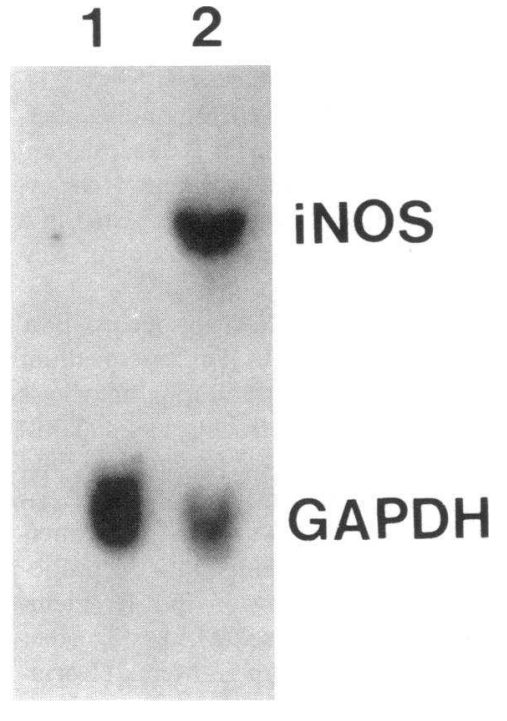

Figure 1. Northern blot analysis of human islets after $6 \mathrm{~h}$ of exposure to IL- $1 \beta$ plus IFN- $\gamma$ plus TNF- $\alpha$. Sequential hybridizations were performed with cDNAs encoding for iNOS and GAPDH. Lane 1 , control; lane 2, cytokinetreated. The figure is representative of two separate experiments.

to increase basal insulin release at $1.7 \mathrm{mM}$ glucose, leading to a diminished insulin increase ratio in response to glucose. An increase in medium insulin accumulation and basal insulin release, coupled to a low insulin increase ratio, may be because of $\beta$-cell damage and passive leakage of insulin. However, the observations that islet morphology was well preserved (data not shown), that there was no decrease in islet DNA content (Table I) or insulin and GAPDH mRNA expression (Fig. 2; see below), and that glucose oxidation rates were not affected (see above) all argue against this possibility. The combinations of cytokines that induced higher medium insulin nitrite accumulation (Table I) also induced higher increase in medium insulin ( Table II). In fact, there was a significant correlation ( $P$ $<0.01$ ) between mean values for medium insulin and medium nitrite accumulation when pooling the data from the various experimental groups.

While TNF- $\alpha$ and IL-6 did not affect islet insulin release (Table II), IFN- $\gamma$ induced a significant decrease in both basal and glucose-stimulated insulin release. An inhibitory effect on glucose-stimulated insulin release was also observed when IFN- $\gamma$ was combined with TNF- $\alpha$. Note that IFN- $\gamma$ failed to induce a significant increase in islet NO production (Table I). We have observed previously that $48 \mathrm{~h}$ of exposure of human islets to IL- $1 \beta$ leads to stimulation of insulin release both at 1.7 and $16.7 \mathrm{mM}$ glucose (17). This may explain why the inhibi-

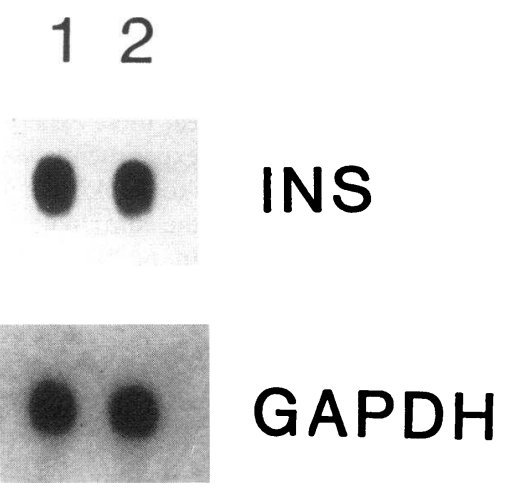

Figure 2. Northern blot analysis of human islets after $30 \mathrm{~h}$ of exposure to IL- $1 \beta$ plus IFN- $\gamma$ plus TNF- $\alpha$. Sequential hybridizations were performed with cDNAs encoding for insulin (INS) and GAPDH. Lane 1, control; lane 2, cytokine-treated. The figure is representative of four separate experiments (see densitometric quantification in the text). 
Table II. Effects of a 48-h Exposure to Cytokines on Medium Insulin Accumulation and Glucose-stimulated Insulin Release of Human Pancreatic Islets

\begin{tabular}{lcccc}
\hline & & \multicolumn{2}{c}{ Insulin release } & \\
\cline { 3 - 4 } \multicolumn{1}{c}{ Cytokines } & $\begin{array}{c}\text { Medium } \\
\text { insulin }\end{array}$ & $\begin{array}{c}1.7 \mathrm{mM} \\
\text { glucose }\end{array}$ & $\begin{array}{c}16.7 \mathrm{mM} \\
\text { glucose }\end{array}$ & $\begin{array}{c}\text { Increase } \\
\text { ratio } \\
(16.7: 1.7)\end{array}$ \\
\hline & $\begin{array}{c}n g / 25 \text { islets } \\
\times 48 \mathrm{~h}\end{array}$ & \multicolumn{2}{c}{$\begin{array}{c}n g / 10 \text { islets } \\
\times 1 \mathrm{~h}\end{array}$} \\
None & $307 \pm 85$ & $2.5 \pm 0.3$ & $12.6 \pm 2.6$ & $7.0 \pm 1.0$ \\
IFN- $\gamma$ & $352 \pm 101$ & $1.5 \pm 0.2^{*}$ & $10.7 \pm 2.6^{*}$ & $7.2 \pm 1.4$ \\
IL-6 & $408 \pm 138$ & $2.4 \pm 0.5$ & $18.5 \pm 8.6$ & $7.2 \pm 1.5$ \\
TNF- $\alpha$ & $472 \pm 197$ & $2.1 \pm 0.5$ & $14.3 \pm 6.0$ & $8.0 \pm 3.2$ \\
IFN- $\gamma$ plus TNF- $\alpha$ & $730 \pm 248$ & $4.3 \pm 1.5$ & $10.0 \pm 3.1^{*}$ & $3.6 \pm 0.6^{\ddagger}$ \\
IFN- $\gamma+$ IL-6 & $1000 \pm 370^{*}$ & $4.9 \pm 1.6$ & $20.4 \pm 8.4$ & $5.5 \pm 1.0$ \\
TNF- $\alpha$ plus IL-6 & $613 \pm 206$ & $6.1 \pm 3.0$ & $11.0 \pm 3.8$ & $3.3 \pm 0.9^{*}$ \\
IFN- $\gamma$ plus TNF- $\alpha$ & & & & \\
$\quad$ plus IL-6 & $719 \pm 225$ & $7.8 \pm 4.9$ & $10.2 \pm 3.3$ & $2.5 \pm 0.4^{\S}$ \\
IL-1 $\beta$ plus TNF- $\alpha$ & & & & \\
$\quad$ plus IFN- $\gamma$ & $1638 \pm 352^{\ddagger}$ & $11.2 \pm 5.2$ & $14.3 \pm 5.8$ & $2.0 \pm 0.7^{\ddagger}$ \\
IL-1 $\beta$ plus TNF- $\alpha$ & & & & \\
$\quad \begin{array}{l}\text { plus IFN- } \gamma \\
\text { plus IL-6 }\end{array}$ & & & & \\
\hline
\end{tabular}

Groups of islets were isolated and exposed to IFN- $\gamma 1,000 \mathrm{U} / \mathrm{ml}$, IL-6 $25 \mathrm{U} / \mathrm{ml}, \mathrm{TNF}-\alpha 1,000 \mathrm{U} / \mathrm{ml}$, and IL- $1 \beta 50 \mathrm{U} / \mathrm{ml}$ as described in Methods. For insulin release experiments, islets were incubated in triplicate groups of 7-10 in KRBH buffer containing $1.7 \mathrm{mM}$ glucose at $37^{\circ} \mathrm{C}$. After $60 \mathrm{~min}$, the medium was removed, and the islets were incubated for another $60 \mathrm{~min}$ in medium containing $16.7 \mathrm{mM}$ glucose. The increase ratio was calculated by dividing the insulin release observed at $16.7 \mathrm{mM}$ glucose by that observed at $1.7 \mathrm{mM}$ glucose. Values are means \pm SEM of $8-10$ experiments. ${ }^{*} P<0.05,{ }^{\ddagger} P<$ $0.01,{ }^{8} P<0.001$, respectively, for a chance difference vs noncytokine-treated control islets.

tory effects of IFN- $\gamma$ were not observed in combinations of cytokines including IL-1 $\beta$ ( Table II).

Mouse islets exposed for $48 \mathrm{~h}$ to IL- $1 \beta$ present a marked decrease in islet insulin content ( 11 ), which is probably secondary to an early (12-24 h) decrease in insulin mRNA (12). To assess if this held true for the observed decrease in islet insulin content in human pancreatic islets (Table I), we determined the insulin mRNA contents of these islets after $30 \mathrm{~h}$ of culture in the absence or presence of IL- $1 \beta$ plus TNF- $\alpha$ plus IFN- $\gamma$ (experimental conditions as in Table I). This treatment induced a fivefold increase in medium nitrite accumulation (data not shown). As shown in Fig. 2, hybridization of Northern blots with the insulin probe yielded the expected $\approx 0.5-\mathrm{kb}$ band. There was no decrease of insulin mRNA in the human islets exposed to combinations of cytokines, as confirmed by densitometric analysis. Thus, the values for insulin mRNA, expressed as arbitrary units of optical density after correction for GAPDH mRNA content, were: controls $1.79 \pm 0.33$, and cytokine-exposed $1.53 \pm 0.33($ mean $\pm S E M ; n=4)$. Exposure of human islets to cytokines did not modify expression of GAPDH mRNA (Fig. 2).

After exposure of islets to a cytokine combination (IL-1 $\beta$ plus TNF- $\alpha$ plus IFN- $\gamma$ ) for $6 \mathrm{~d}$, islet recovery was $>95 \%$ in all experimental groups, and this was not affected by the presence of cytokines or inhibitors of NO generation (data not shown). Similarly, islet DNA content was not modified significantly by any of the treatments (Table III). However, there was a marked decrease in islet insulin content in the cytokine-treated group, and this decrease was not prevented by L-nitroarg. It should be noted that AG itself caused a lowering of the insulin content, as compared with the control group (Table III, None; $P<0.01$ ), and as a result there was no difference in islet insulin content between the AG and the AG plus cytokine group. The cytokine combination induced an almost fourfold increase in medium nitrite accumulation over the $6 \mathrm{~d}$ of exposure (Table III). The stimulatory effects of cytokines on nitrite accumulation were sustained at similar levels between days 1 and 2, 3 and 4 , and 5 and 6 of culture (data not shown), enabling us to pool these data in Table III. Both AG and L-nitroarg effectively prevented cytokine-induced nitrite accumulation $(P<0.01$ vs islets exposed to IL- $1 \beta$ alone). After the 6-d period there was a similar $20-40 \%$ decrease in glucose oxidation rates in islets exposed to cytokines in the presence or absence of AG or L-nitroarg, as compared with their respective control groups ( Table III). However, this difference reached statistical significance only in the AG-cytokine group.

As observed previously (Table II), there was a fivefold increase in medium insulin accumulation during the first $2 \mathrm{~d}$ of cytokine exposure (Table IV). After 3-4 d there was still a

Table III. Effects of 6 d of Exposure to Cytokines (IL-1 $\beta$ plus TNF- $\alpha$ plus IFN- $\gamma$ ) and/or Inhibitors of NO Generation on Insulin and DNA Content, Nitrite Production, and Glucose Oxidation of Human Islets

\begin{tabular}{lcccc}
\hline \multicolumn{1}{c}{ Treatment } & Insulin content & DNA content & Medium nitrite & Glucose oxidation \\
& $n g / 10$ islets & $n g / 10$ islets & $p m o l /$ islet $\times 6 d$ & $p m o l / 10$ islets $\times 1.5 h$ \\
None & $577 \pm 101(8)$ & $404 \pm 58(9)$ & $20.1 \pm 6.7(6)$ & $131 \pm 18(6)$ \\
Cytokines & $98 \pm 14(8)^{*}$ & $336 \pm 67(9)$ & $76.3 \pm 13.5(6)^{*}$ & $102 \pm 16(6)$ \\
AG & $192 \pm 51(4)$ & $403 \pm 83(5)$ & $7.9 \pm 2.7(5)$ & $134 \pm 18(4)$ \\
AG plus cytokines & $132 \pm 37(4)$ & $451 \pm 82(5)$ & $11.6 \pm 1.7(5)$ & $97 \pm 19(4)^{\ddagger}$ \\
L-nitroarg & $699 \pm 197(3)$ & $527 \pm 87(3)$ & $13.5 \pm 1.7(3)$ & $105 \pm 3(2)$ \\
L-nitroarg plus cytokines & $143 \pm 44(3)^{*}$ & $440 \pm 101(3)$ & $18.6 \pm 8.7(3)$ & $61 \pm 1(2)$ \\
\end{tabular}

Groups of islets were isolated and exposed to cytokines (IL-1 $\beta 50 \mathrm{U} / \mathrm{ml}$ plus TNF- $\alpha 1,000 \mathrm{U} / \mathrm{ml}$ plus IFN- $\gamma 1,000 \mathrm{U} / \mathrm{ml}$ ) and/or inhibitors of NO generation (AG $5 \mathrm{mM}$ or L-nitroarg $5 \mathrm{mM}$ ) for $6 \mathrm{~d}$ as described in Methods. Rates of glucose oxidation were measured in triplicate groups of $10-15$ islets incubated for $90 \mathrm{~min}$ in KRBH buffer (without albumin) supplemented with $D-\left[\mathrm{U}-{ }^{14} \mathrm{C}\right]$ glucose and $16.7 \mathrm{mM}$ nonradioactive glucose. The results are means \pm SEM of the number of experiments indicated in the parentheses. ${ }^{\ddagger} P<0.05 ;{ }^{*} P<0.01$ when compared with the respective controls. 
Table IV. Effects of $6 d$ of Exposure to Cytokines (IL-1 $1 \beta$ plus TNF- $\alpha$ plus IFN- $\gamma$ ) and/or Inhibitors of NO Generation on Medium Insulin Accumulation of Human Pancreatic Islets

\begin{tabular}{lccc}
\hline \multirow{2}{*}{\multicolumn{1}{c}{ Treatment }} & \multicolumn{3}{c}{ Insulin accumulation in the medium } \\
\cline { 2 - 4 } & Days 1 and 2 & Days 3 and 4 & Days 5 and 6 \\
\hline \multirow{4}{c}{$n g / 25$ islets $\times 48 h$} \\
None & $228 \pm 29(9)$ & $230 \pm 63$ & $205 \pm 37$ \\
Cytokines & $1227 \pm 321(9)^{*}$ & $399 \pm 76^{*}$ & $283 \pm 59$ \\
AG & $353 \pm 50(5)$ & $329 \pm 62$ & $303 \pm 79$ \\
AG plus cytokines & $560 \pm 78(5)$ & $268 \pm 48$ & $316 \pm 46$ \\
L-nitroarg & $242 \pm 46(3)$ & $279 \pm 9$ & $288 \pm 28$ \\
L-nitroarg plus cytokines & $1808 \pm 580(3)^{*}$ & $645 \pm 43^{\ddagger}$ & $451 \pm 30^{*}$ \\
& & & \\
\hline
\end{tabular}

Groups of islets were isolated and exposed to cytokines (IL- $1 \beta 50 \mathrm{U} /$ $\mathrm{ml}$ plus TNF- $\alpha 1,000 \mathrm{U} / \mathrm{ml}$ plus IFN- $\gamma 1,000 \mathrm{U} / \mathrm{ml}$ ) and/or inhibitors of NO generation (AG $5 \mathrm{mM}$ or L-nitroarg $5 \mathrm{mM}$ ) for $6 \mathrm{~d}$, as described in Methods. Medium was collected for insulin determinations at $48-\mathrm{h}$ intervals. The results are means \pm SEM of the number of experiments indicated in the parentheses. ${ }^{*} P<0.05 ;{ }^{\ddagger} P<0.01$ when compared with the respective controls.

1.5-fold increase in medium insulin in the cytokine-treated group, which disappeared, however, on the last $2 \mathrm{~d}$ of observation. The increase in medium insulin induced by cytokines was prevented by AG over the whole period of observation but it was not prevented by L-nitroarg. Note that both drugs induced similar inhibition of NO production (Table III).

Glucose-induced insulin release was affected markedly by the 6-d exposure to cytokines (Table V). Thus, there was a $\approx 55 \%$ decrease in insulin release at the higher glucose concentration, as compared with control islets. Moreover, while control islets presented a ninefold insulin increase ratio in response to glucose, cytokine-treated islets barely responded to glucose. AG failed to prevent cytokine-induced decrease in insulin release. Thus, the AG plus cytokine group also presented a $55 \%$ decrease in insulin release at $16.7 \mathrm{mM}$ glucose. Furthermore, even when considering that the increase ratio in the AG group was less than that observed in the control group (Table V, None; $P<0.08$ ), the inhibitory effect of cytokines was still present. Essentially the same pattern was observed with L-nitroarg. Thus, the drug failed to prevent both cytokine-induced decrease in insulin release at $16.7 \mathrm{mM}$ glucose and cytokine-induced decrease in the increase ratio. The observations with $\mathrm{N}$-arg are of special relevance, since the absolute insulin release and increase ratio of the L-nitroarg group were similar to the corresponding values in the control (Table V, None) group.

\section{Discussion}

None of the tested cytokines by themselves induced NO production in human pancreatic islet, as was also the case in the recent study by Corbett et al. (18). In the case of TNF- $\alpha$ and IL-6, this was paralleled by a lack of effect on human islet function (present data) and, in the case of IL-1 $\beta$, by stimulation of insulin release (17). IFN- $\gamma$ decreased islet insulin release mildly but significantly, independent of an increase in NO generation. When different combinations of cytokines were tested, IL- $1 \beta$ plus IFN- $\gamma$ plus TNF- $\alpha$ was the most effective combination in inducing increased NO production. This
Table V. Effects of $6 \mathrm{~d}$ of Exposure to Cytokines (IL-1 $\beta$ plus $T N F-\alpha$ plus IFN- $\gamma$ ) and/or Inhibitors of NO Generation on Glucose-induced Insulin Release

\begin{tabular}{|c|c|c|c|c|}
\hline \multirow[b]{2}{*}{ Treatment } & \multicolumn{2}{|c|}{ Insulin release } & \multirow[b]{2}{*}{$\begin{array}{l}\text { Percentage } \\
\text { of control }\end{array}$} & \multirow[b]{2}{*}{$\begin{array}{c}\text { Increase ratio } \\
16.7: 1.7\end{array}$} \\
\hline & $\begin{array}{l}1.7 \mathrm{mM} \\
\text { glucose }\end{array}$ & $\begin{array}{l}16.7 \mathrm{mM} \\
\text { glucose }\end{array}$ & & \\
\hline \multicolumn{5}{|c|}{$n g / 10$ islets $\times 1 h$} \\
\hline None & $3.2 \pm 0.9(9)$ & $18.1 \pm 2.4$ & 一 & $9.2 \pm 2.4$ \\
\hline Cytokines & $4.9 \pm 0.7(9)$ & $7.6 \pm 1.0^{*}$ & $43 \pm 5^{*}$ & $1.6 \pm 0.2^{\ddagger}$ \\
\hline AG & $4.2 \pm 1.1(5)$ & $10.5 \pm 2.1$ & - & $2.8 \pm 0.5$ \\
\hline AG plus cytokines & $2.4 \pm 0.4(5)$ & $4.1 \pm 0.5^{8}$ & $45 \pm 10^{\S}$ & $1.8 \pm 0.2^{\ddagger}$ \\
\hline L-nitroarg & $4.4 \pm 2.1(3)$ & $16.8 \pm 2.0$ & - & $6.2 \pm 2.5$ \\
\hline $\begin{array}{l}\text { L-nitroarg plus } \\
\text { cytokines }\end{array}$ & $10.5 \pm 2.8(3)$ & $9.4 \pm 0.6^{8}$ & $57 \pm 4^{\S}$ & $1.0 \pm 0.2$ \\
\hline
\end{tabular}

Groups of islets were isolated and exposed to cytokines (IL-1 $\beta 50 \mathrm{U} /$ $\mathrm{ml}$ plus TNF- $\alpha 1,000 \mathrm{U} / \mathrm{ml}$ plus IFN- $\gamma 1,000 \mathrm{U} / \mathrm{ml}$ ) and/or inhibitors of NO generation (AG $5 \mathrm{mM}$ or L-nitroarg $5 \mathrm{mM}$ ) as described in Methods. For insulin release experiments, islets were incubated in triplicate groups of 7-10 and sequentially exposed to 1.7 or $16.7 \mathrm{mM}$ glucose, as described in Table II. Percentage of control was calculated by comparing insulin release at $16.7 \mathrm{mM}$ glucose between islets exposed to cytokines vs respective controls, i.e., islets exposed to the same inhibitor of NO generation in the absence of cytokines. The increase ratio was calculated by dividing the insulin release observed at $16.7 \mathrm{mM}$ glucose by that observed at $1.7 \mathrm{mM}$ glucose. The results are means \pm SEM or the number of experiments indicated in the parentheses. ${ }^{\ddagger} P<0.05 ;{ }^{\S} P<0.01 ;{ }^{*} P<0.001$ when compared with respective controls.

was accompanied by expression of iNOS mRNA, and to our knowledge this is the first demonstration of this transcript in human pancreatic islets. The cytokine-induced increase in medium nitrite accumulation over a 48 -h period (present data) was similar to that observed previously with rat islets exposed to IL- $1 \beta(9,17)$ or mouse islets exposed to IL- $1 \beta$ plus IFN- $\gamma$ plus TNF- $\alpha$ for 48 h (Cetkovic-Cvrlje, M., and D. L. Eizirik, manuscript submitted for publication). In rodent islets this is associated with a marked $\beta$-cell dysfunction, as indicated by decreased insulin accumulation in the medium, impaired insulin response to glucose, and decreased rates of glucose oxidation (6). In human islets exposed for $48 \mathrm{~h}$ to homologous cytokines (present data), there was an increased insulin accumulation into the culture medium, well preserved levels of insulin release at $16.7 \mathrm{mM}$ glucose, and normal glucose oxidation rates. These findings suggest that human islets are more resistant than rodent islets to deleterious effects of NO. Interestingly, human islets are also more resistant than both rat and mouse pancreatic islets to both the toxic effects of streptozotocin, a $\beta$-cell toxin which like NO (9) seems to induce impairment in mitochondrial function (36), and to the deleterious effects of sodium nitroprusside, a chemical generator of NO (Eizirik, D. L., B. Margulis, N. Welsh, and C. Hellerström, manuscript in preparation). On the other hand, human islets are more susceptible than rodent islets to the deleterious effects of high glucose (19). Thus, it seems that human islets exhibit a pattern of susceptibility and/or resistance to noxious agents that is different from that observed in rodent islets. It remains to be clarified if this is a consequence of triggering more efficient and/or different repair mechanisms (3). 
The comparison on the species sensitivity to cytokines is hampered by the lack of a systematic dose-response and time course analysis on the effects of cytokines on human islets. Since the scarcity of human islets precludes performing such a study in a comprehensive way, i.e., using several different human islet preparations, we choose to expose human islets to high concentrations of cytokines, equal or two- to threefold higher than concentrations shown previously to affect rodent islets $(5,6)$. Thus, the present data do not exclude that higher concentration of cytokines or longer exposure periods may lead eventually to more severe impairment in human islet function and $\beta$-cell death. However, it must be pointed out that higher concentrations of cytokines than the ones used presently would approach pharmacological levels.

The most prominent alteration induced in human islets by the 48-h exposure to combinations of cytokines was a marked decrease in islet insulin content. Two possible explanations for this observation are increased insulin release, not compensated for by a sufficient increase in insulin biosynthesis, and/or a primary decrease in insulin mRNA, leading to a decrease in insulin biosynthesis. Previous studies suggest that the latter mechanism is probably the cause of the decreased insulin content observed in mouse pancreatic islets exposed to IL- $1 \beta$ ( 11 , 12 ). Indeed, a decreased insulin mRNA is already observed after $12 \mathrm{~h}$ of culture in the presence of the cytokine, preceding the decrease in insulin content, which is observed only after 24-48 h (12). However, this mechanism does not seem to operate in human islets. Thus, the present data show that even $30 \mathrm{~h}$ of exposure to combinations of cytokines did not decrease insulin mRNA content. Although it cannot be excluded that longer periods of exposure of human islets to cytokines may deplete insulin mRNA, the present observations make it unlikely that this is an early and primary event. Considering that both IL- $1 \beta$ plus TNF- $\alpha$ plus IFN- $\gamma$ and IL- $1 \beta$ plus TNF- $\alpha$ plus IFN- $\gamma$ plus IL- 6 , the two combinations of cytokines that induced the most marked decrease in islet insulin content, also induced the highest accumulation of insulin in the medium, it seems likely that the hormone depletion in the $\beta$-cells is, at least in part, secondary to increased insulin release.

When the exposure time to cytokines was prolonged to $6 \mathrm{~d}$, the insulin accumulation in the medium returned to basal levels after 5-6 d. There was again a severe hormone depletion in the cells and a $60 \%$ decrease in glucose-induced insulin release, suggesting impaired islet function. In rat islets $(6,35)$ the suppressive effects of cytokines on insulin release are related to a marked impairment in glucose oxidation. This was not the case in mouse islets $(11,13)$ and seems neither to occur in human islets. The absence of a marked reduction in islet DNA content further argues against a clear cytokine-induced toxicity to human islets, at least during a 6-d exposure. The present data are more compatible with a cytokine-induced functional suppression rather than cytokine-induced $\beta$-cell death.

The mechanism(s) of this suppression is still unknown. The parallel between $\beta$-cell dysfunction and increased nitrite accumulation into the medium favors a role for NO in human $\beta$-cell dysfunction. However, inhibition of NO generation by AG or L-nitroarg did not protect against the inhibitory effects of cytokines (present data), while this was clearly the case in rodent islets $(8,9,37)$. The present study thus argues against the view that NO is the main mediator of the inhibitory effects of cytokines on human pancreatic islets (18). Two alternative possibilities should be considered. First, cytokines may lead to islet functional "exhaustion," by markedly increasing human islet insulin release, as observed in human islets cultured for $6 \mathrm{~d}$ in the presence of high glucose concentrations (19). Second, combinations of cytokines may induce the synthesis of other toxic radicals, like hydrogen peroxide, superoxide, and the hydroxyl radical, as suggested for rat islets exposed to similar cytokines $(5,38,39)$. NO has been proposed to be an important mediator of $\beta$-cell damage in human $\operatorname{IDDM}(40,41)$. This hypothesis was based mostly on data obtained using rat pancreatic islets, a species in which $\beta$-cells are particularly susceptible to NO toxicity. The present findings, obtained with a large number of well defined human islet preparations, suggest that further investigations must be carried out before in vitro studies performed on rodent islets can be extrapolated to human IDDM. Another possibility in the context of IDDM is that the main source of NO generation in the vicinity of the $\beta$-cells is nonendocrine cells, such as invading macrophages (41), which can produce cytokines as well as large amounts of NO. It is conceivable that macrophage-generated NO, together with cytokine-induced NO and/or other radical(s), could then contribute to $\beta$-cell destruction.

\section{Acknowledgments}

The excellent technical assistance of I.-B. Hallgren, E. Törnelius, E. Forsbeck, A. Nordin, and M. Engkvist is acknowledged. This study made use of human islets prepared by the Central Unit of the $\beta$-Cell Transplant.

This study was supported by a concerted action in Medical and Health Research of the European Community. The study was also supported by grants from the Swedish Medical Research Council (12X-9237, connected to the $\beta$-Cell Transplant, European Concerted Action for the Treatment of Diabetes, 12X-109, 12X-9886, 12X-8273, and 12P-10739), the Juvenile Diabetes Foundation International, the Swedish Diabetes Association, the Swedish Centrala Försöksdjursnämnden ("Forskringsanslag för alternative Metoder"), the NovoNordisk Insulin Fund, the Aage Louis-Hanseen Fund, the Family Ernfors Fund, the Danish Biotechnology Programme, and an Eli Lilly/ European Association for the Study of Diabetes Research Fellowship in Diabetes and Metabolism.

\section{References}

1. Eisenbarth, G. S. 1986. Type I diabetes mellitus. A chronic autoimmune disease. N. Engl. J. Med. 314:1360-1368.

2. Skyler, J. S., and J. B. Marks. 1993. Immune intervention in type I diabetes mellitus. Diabetes Rev. 1:15-42.

3. Eizirik, D. L., S. Sandler, and J. P. Palmer. 1993. Repair of pancreatic $\beta$-cells. A relevant phenomenon in early IDDM? Diabetes. 42:1383-1391.

4. Bendtzen, K. 1989. Immune hormones (cytokines); pathogenetic role in autoimmune arthritis and endocrine diseases. Autoimmunity. 2:177-189.

5. Mandrup-Poulsen, T., S. Helqvist, L. D. Wogensen, J. Mølvig, F. Pociot, J. Johannensen, and J. Nerup. 1990. Cytokines and free radicals as effector molecules in the destruction of pancreatic $\beta$-cells. Curr. Top. Microbiol. Immunol. 164:169-193.

6. Sandler, S., D. L. Eizirik, C. Svensson, E. Strandell, M. Welsh, and N. Welsh. 1991. Biochemical and molecular actions of interleukin-1 on pancreatic $\beta$-cells. Autoimmunity. 10:241-253.

7. Ling, Z., P. A. In't Veld, and D. G. Pipeleers. 1993. Interactions of interleukin- 1 with islet $\beta$-cells. Distinction between indirect, aspecific cytotoxicity and direct, specific functional suppression. Diabetes. 42:56-65.

8. Southern, C., D. Schulster, and I. C. Green. 1990. Inhibition of insulin secretion by interleukin- $1 \beta$ and tumor necrosis factor- $\alpha$ via an $\mathrm{L}$-arginine dependent nitric oxide generating mechanism. FEBS (Fed. Eur. Biochem. Soc.) Lett. 276:42-44.

9. Welsh, N., D. L. Eizirik, K. Bendtzen, and S. Sandler. 1991. Interleukin-1 $\beta$ induced nitric oxide production in isolated rat pancreatic islets requires gene transcription and may lead to inhibition of the Krebs cycle enzyme aconitase. Endocrinology. 129:3167-3173. 
10. Corbett, J. A., J. R. Lancaster, Jr., M. A. Sweetland, and M. L. McDaniel. 1991. Interleukin- $1 \beta$-induced formation of EPR-detectable iron-nytrosil complexes in islets of Langerhans. Role of nitric oxide in interleukin-1 $\beta$-induced inhibition of insulin secretion. J. Biol. Chem. 266:21351-21354.

11. Eizirik, D. L., M. Welsh, E. Strandell, N. Welsh, and S. Sandler. 1990. Interleukin- $1 \beta$ depletes insulin messenger ribonucleic acid and increases the heat shock protein hsp70 in mouse pancreatic islets without impairing the glucose metabolism. Endocrinology. 127:2290-2297.

12. Eizirik, D. L. 1991. Interleukin-1 induces an early decrease in insulin release, (pro)insulin biosynthesis and insulin mRNA in mouse pancreatic islets by a mechanism dependent on gene transcription and protein biosynthesis. Autoimmunity. 10:107-113.

13. Welsh, N., and S. Sandler. 1992. Interleukin- $1 \beta$ induces nitric oxide production and inhibits the activity of aconitase without decreasing glucose oxidation rates in isolated mouse pancreatic islets. Biochem. Biophys. Res. Commun. 182:333-340.

14. Rabinovitch, A., W. Sumoski, R. V. Rajotte, and G. L. Warnock. 1990. Cytotoxic effects of cytokines on human pancreatic islets in monolayer culture. $J$. Clin. Endocrinol. \& Metab. 71:152-156.

15. Kawahara, D. J., and J. S. Kenney. 1991. Species difference in human and rat islet sensitivity to human cytokines. Monoclonal anti-interleukin-1 (IL-1) influences on direct and indirect IL-1-mediated islet effects. Cytokine. 3:117-124.

16. Soldevila, G., M. Buscema, M. Doshi, R. F. L. James, G. F. Bottazzo, and R. Pujol-Borrel. 1991. Cytotoxic effects of IFN- $\gamma$ plus TNF- $\alpha$ on human islet cells. J. Autoimmun. 4:291-306.

17. Eizirik, D. L., N. Welsh, and C. Hellerström. 1993. Predominance of stimulatory effects of interleukin- $1 \beta$ on isolated human pancreatic islets. J. Clin. Endocrinol. \& Metab. 76:399-403.

18. Corbett, J. A., M. A. Sweetland, J. L. Wang, J. R. Lancaster, Jr., and M. L. McDaniel. 1993. Nitric oxide mediates cytokine-induced inhibition of insulin secretion by human islets of Langerhans. Proc. Natl. Acad. Sci. USA 90:17311735 .

19. Eizirik, D. L., G. S. Korbutt, and C. Hellerström. 1992. Prolonged exposure of human pancreatic islets to high glucose concentrations in vitro impairs the $\beta$-cell function. J. Clin. Invest. 90:1263-1268.

20. Svenson, M., and K. Bendtzen. 1988. Interleukin-1 inhibitor in normal human urine. Different effects on mouse thymocytes and on a murine T-cell line. Scand. J. Immunol. 27:593-599.

21. Aarden, L. A., E. R. de Groot, O. L. Schaap, and P. M. Lansdorp. 1987. Production of hybridoma growth factor by human monocytes. Eur. J. Immunol. 17:1411-1416.

22. Fomsgaard, A., H. Worsaac, and K. Bendtzen. 1988. Detection of tumor necrosis factor from lipopolysaccharide-stimulated human mononuclear cells by enzyme-linked immunoabsorbent assay and cytotoxicity bioassay. Scand. J. Immunol. 27:143-147.

23. Bendtzen, K., N. Morling, A. Fomsgaard, M. Svenson, B. Jakobsen, N. Ødun, and A. Svejgaard. 1988. Association between HLA-DR2 and production of tumour necrosis factor- $\alpha$ and interleukin-1 by mononuclear cells activated by lipopolysaccharide. Scand. J. Immunol. 28:599-606.

24. Sandler, S., K. Bendtzen, D. L. Eizirik, and M. Welsh. 1990. Interleukin-6 affects insulin secretion and glucose metabolism of rat pancreatic islets in vitro. Endocrinology. 126:1288-1294.
25. Misko, T. P., W. M. Moore, T. P. Kasten, G. A. Nickols, J. A. Corbett, R. G. Tilton, M. L. McDaniel, J. R. Williamson, and M. G. Currie. 1993. Selective inhibition of the inducible nitric oxide synthase by aminoguanidine. Eur. $J$. Pharmacol. 233:119-126.

26. Heding, L. G. 1972. Determination of total serum insulin (IRI) in insulintreated diabetic patients. Diabetologia. 8:260-266.

27. Krebs, H. A., and K. Henseleit. 1932. Untersuchugen über die Harnstoffbildung im Tierkörper. Hoppe-Seyler's Z. Physiol. Chem. 210:33-66.

28. Andersson, A., and S. Sandler. 1983. Viability tests of cryopreserved endocrine pancreatic cells. Cryobiology. 20:161-168.

29. Chirgwin, P., A. W. Przybyla, R. J. MacDonald, and W. J. Rutter. 1979. Isolation of biologically active ribonucleic acid from sources enriched in ribonuclease. Biochemistry. 18:5294-5299.

30. Geller, D. A. C. J. Lowenstein, R. A. Shapiro, A. K. Nussler, M. D. Silvio, S. C. Wang, D. K. Nakayama, R. L. Simmons, S. H. Snyder, and T. R. Billiar 1993. Molecular cloning and expression of inducible nitric oxide synthase from human hepatocytes. Proc. Natl. Acad. Sci. USA. 90:3491-3495.

31. Eizirik, D. L., A. Björklund, and E. Cagliero. 1993. Genotoxic agents increase expression of growth arrest and DNA damage-inducible genes gadd 153 and gadd 45 in rat pancreatic islets. Diabetes. 42:738-745.

32. Chan, S. J., B. E. Noyes, K. L. Agarwal, and D. F. Steiner. 1979. Construction and selection of recombinant plasmids containing full-length complementary DNAs corresponding to rat insulins I and II. Proc. Natl. Acad. Sci. USA. 76:5036-5040.

33. Wallenstein, S., C. L. Zucker, and J. Fleiss. 1980. Some statistical methods useful in circulation research. Circ. Res. 47:1-9.

34. Eizirik, D. L., A. Björklund, and N. Welsh. 1993. Interleukin-1-induced expression of nitric oxide synthase in insulin-producing cells is preceded by $c$-fos induction and depends on gene transcription and protein synthesis. FEBS (Fed. Eur. Biochem. Soc.) Lett. 317:62-66.

35. Borg, L. A. H., and D. L. Eizirik. 1990. Short-term exposure of rat pancreatic islets to human interleukin- $1 \beta$ increases cellular uptake of calcium. Im munol. Lett. 26:253-258.

36. Eizirik, D. L., S. Sandler, A. Sener, and W. J. Malaisse. 1988. Defective catabolism of D-glucose and L-glutamine in mouse pancreatic islets maintained in culture after streptozotocin exposure. Endocrinology. 123:1001-1007.

37. Corbett, J. A., R. G. Tilton, K. Chang, K. S. Hasan, Y. Ido, J. L. Wang M. A. Sweetland, J. R. Lancaster, Jr., J. R. Williamson, and M. L. McDaniel. 1992. Aminoguanidine, a novel inhibitor of nitric oxide formation, prevents diabetic vascular dysfunction. Diabetes. 41:552-556.

38. Sumoski, W., H. Baquerizo, and A. Rabinovitch. 1989. Oxygen free radical scavengers protect rat islet cells from damage from cytokines. Diabetologia. 32:792-796.

39. Rabinovitch, A., W. L. Suarez, P. D. Thomas, K. Strynadka, and I. Simpson. 1992. Cytotoxic effects of cytokines on rat islets: evidence for involvement of free radicals and lipid peroxidation. Diabetologia. 35:409-413.

40. Corbett, J. A., and M. L. McDaniel. 1992. Does nitric oxide mediate autoimmune destruction of $\beta$-cells? Possible therapeutic interventions in IDDM Diabetes. 41:897-903.

41. Kolb, H., and V. Kolb-Bachofen. 1992. Type 1 (insulin-dependent) diabetes mellitus and nitric oxide. Diabetologia. 35:796-797. 